\title{
ERIMI-LAONIN TOU PORAKOU (LIMASSOL, CYPRUS): RADIOCARBON ANALYSES OF THE BRONZE AGE CEMETERY AND WORKSHOP COMPLEX
}

\author{
C Scirè Calabrisotto ${ }^{1,2} \cdot \mathrm{M} \mathrm{E} \mathrm{Fedi}^{3} \cdot \mathrm{L} \mathrm{Caforio}^{3,4} \cdot \mathrm{L} \mathrm{Bombardieri}^{1}$
}

\begin{abstract}
The site area of Erimi-Laonin tou Porakou (Limassol, Cyprus) has been surveyed and systematically excavated since 2007 as a joint research project of the University of Florence and the Department of Antiquities of Cyprus. A focused investigation was dedicated to analyzing funerary evidence from the southern Cemetery (Area E), where 7 singlechamber graves were excavated. The offering goods assemblages from the burials point to a general date ranging from Early to Late Bronze Age I, and draw a sequence of use that is contemporary to the stratigraphic deposits from the top mound Workshop Complex (Area A). During the 2010 field season, charcoal samples from the Workshop Complex and bone samples from the skeleton remains of 2 burials (tombs 228,230 ) were opportunely taken for radiocarbon analyses. ${ }^{14} \mathrm{C}$ dating was performed at the AMS-IBA Tandetron accelerator of the INFN-LABEC Laboratory in Florence. This paper will discuss the results of the ${ }^{14} \mathrm{C}$ analyses and compare them with the archaeological evidence in order to outline a chronological sequence for the settlement and cemetery areas at Erimi-Laonin tou Porakou, thus collecting further data on the development and pattern of occupation of the Early to Late Cypriote period in the Kourion area.
\end{abstract}

\section{INTRODUCTION}

Erimi-Laonin tou Porakou is located in southern Cyprus, in the Limassol District, lying on a high plateau on the eastern slope of the Kouris River, facing the modern Kouris Dam to the south (Cadastral Sheet LIII/46, Plots 331-336, 384; 34 $42^{\prime} 43^{\prime \prime} \mathrm{N}, 32^{\circ} 55^{\prime} 23^{\prime \prime} \mathrm{E}$ ), just on the border between the Ypsonas and Erimi villages (Figure 1a). The site was first identified as a result of a survey project conducted on the middle and lower Kouris Valley with the purpose of outlining the general patterns of landscape use and the sequence of ancient occupation in the valley area (Bombardieri 2010).

Preliminary evidence paved the way for further investigations focusing on better clarifying the terms of occupation and possibly understanding the function and use of the different areas of the site: Area A, the Workshop Complex, located on the top mound; Area B, the domestic unit, on the first lower terrace; Area E, the Cemetery, covering 2 southern terraces (Figure 1b). As recorded by survey collections and excavation results, the general chronology of the settlement sequence in the area point to an occupation lasting 2 main periods (periods 1 and 2). Up to now, Period 2 is the most documented, ranging from the end of the Early Cypriote to Late Cypriote I (EC III-LC I), with 2 phases evidenced within the sequence (phases A and B). The more recent Period 1, apparently following a lengthy hiatus, testifies a possible resettlement during the late Hellenistic and Roman periods, until now only documented by intensive survey operations on the top mound area and few stratified materials from the small survey Trench B2, located in Area B (Bombardieri 2009).

During the 2010 field season, charcoal samples from Area A, the Workshop Complex, and bone samples from 2 burials (tombs 228, 230) of the Cemetery Area E were collected for radiocarbon analyses. Our purpose was to cross-check the chronological sequence obtained by archaeological evidence and, in a wider perspective, to offer a substantial contribution to the few existing absolute dates of the period (see e.g. Manning and Swiny 1994; Manning et al. 2001; Frankel and Webb 2006).

\footnotetext{
'Dipartimento di Scienze dell'Antichità, Università di Firenze, Piazza Brunelleschi 4, 50121 Firenze, Italy.

${ }^{2}$ Dipartimento di Fisica e Astronomia, Università di Firenze, via Sansone 1, 50019 Sesto Fiorentino (Fi), Italy. Corresponding author. Email: caterinascire@gmail.com

${ }^{3}$ INFN Sezione di Firenze, via Sansone 1, 50019 Sesto Fiorentino (Fi), Italy.

${ }^{4}$ Dipartimento di Fisica, Università di Ferrara, via Saragat 1, 44121 Ferrara, Italy.
}

(C) 2012 by the Arizona Board of Regents on behalf of the University of Arizona Proceedings of the 6th International Radiocarbon and Archaeology Symposium, edited by E Boaretto and N R Rebollo Franco RADIOCARBON, Vol 54, Nr 3-4, 2012, p 475-482 

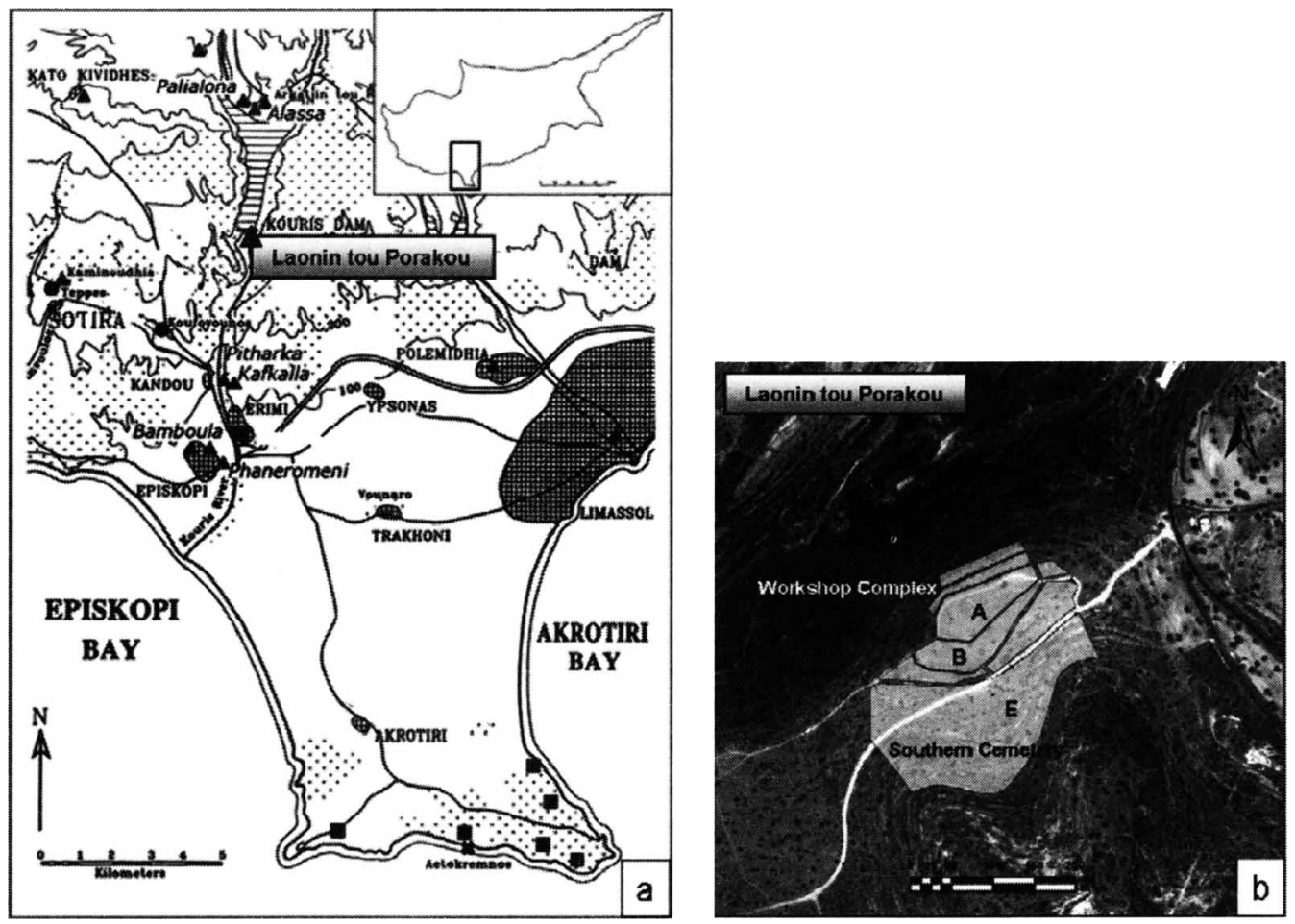

Figure 1 a) Location of the site area of Erimi-Laonin tou Porakou; b) View of the 3 areas of the site: Area A, the Workshop Complex; Area B, the domestic unit; Area E, the Cemetery.

\section{AREA A AND AREA E: THE ARCHAEOLOGICAL EVIDENCE}

\section{Area A: The Workshop Complex}

The Workshop Complex cleared on the top mound of Area A extends over an area of $20 \times 15 \mathrm{~m}$ that is currently being investigated. This complex highlights the organization of 2 distinctive functional spaces: a system of 5 working areas and a wide storage area (see Figure 2). As far as the chronology is concerned, the interpretation of the stratigraphic deposits and analyses of the ceramic assemblage of the Workshop complex reveal use of this area throughout 2 main phases for which 2 possible ranges can be suggested: Early Cypriote III-Middle Cypriote I/II (EC III-MC I/II) for the earlier phase B, and Middle Cypriote III-Late Cypriote I (MC III-LC I) for the more recent phase A (Bombardieri, forthcoming).

The whole area lies on a natural limestone bedrock that had been carefully worked in order to construct a combined system of 5 discrete working areas (WA I-V), characterized by deep basins carved at different depths and connected to each other by incoming and outgoing flow channels. The storage area (SA I) extends $9.50 \times 5.60 \mathrm{~m}$ and its limits were originally cut into the limestone bedrock (in the same fashion as the nearby basins), thus creating an underground floor. The entrance to the storage area has been also evidenced throughout the southeastern limit wall; a huge limestone squared block, used as a threshold, was carefully dressed in order to create a step to access the floor of the storage area. 


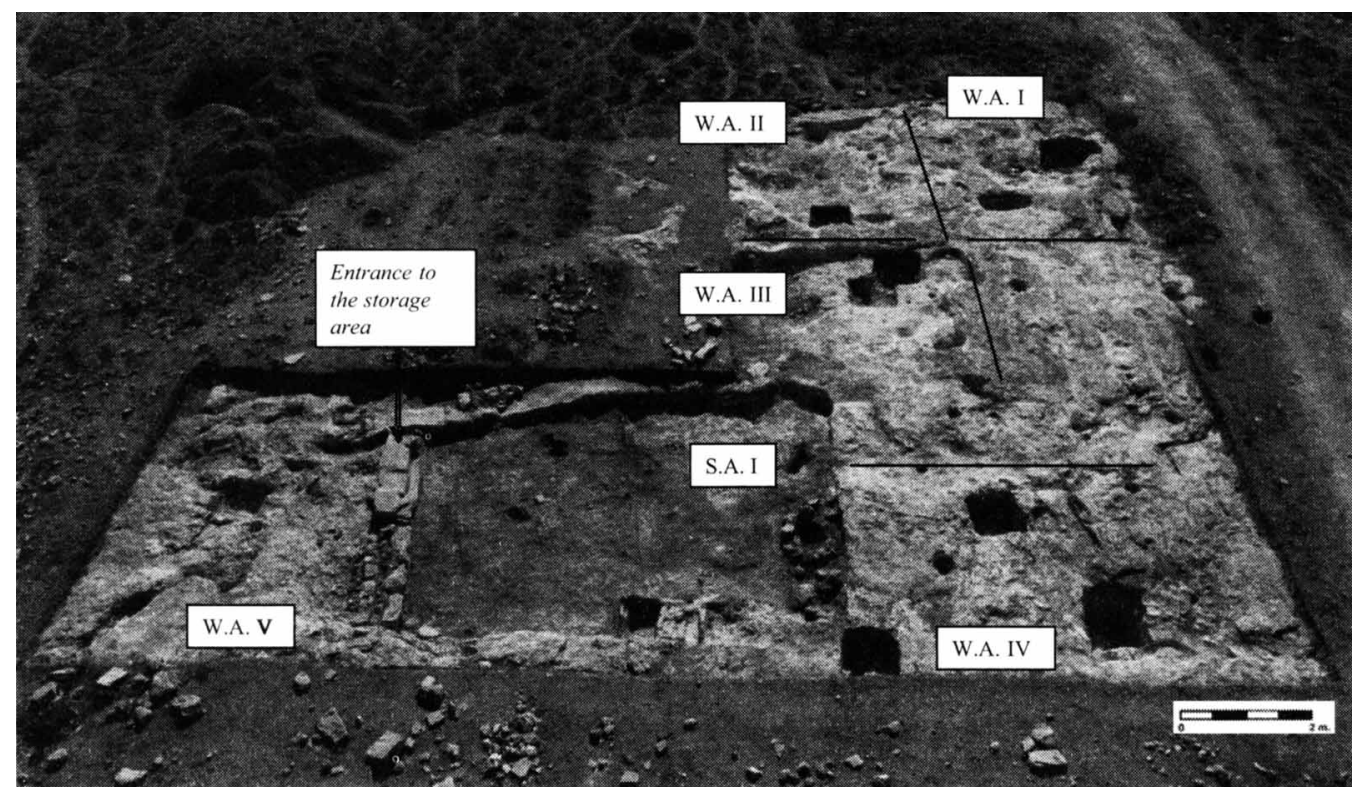

Figure 2 Area A: the Workshop Complex

This kind of working facility is uncommon in the Kourion region and only a few counterparts are known thus far. A basin that may recall the installations at Erimi-Laonin tou Porakou can be found in the nearby site of Erimi-Kafkalla, even though, in this case, the evidence only comes from preliminary surveys made during rescue operations in the area (Belgiorno 2005; Bombardieri and Chelazzi, forthcoming).

Given the characteristics of the working devices and the relevance attributed to the storage area, what emerges here is a Workshop Complex where different steps of homogeneous activities were performed in distinctive working areas, while the storage area was dedicated to collecting and preserving raw materials, processed materials, and/or final products. The recent results of macrocharacterization analyses carried out at the University of Bologna (M L Carra, personal communication, 2011) on filling soils sampled from storage pithoi in the storage area, revealed interesting data to hypothesize a functional interpretation for the Workshop Complex. The samples thus far collected do not contain any trace of cultivated plant remains, nor olives, wheat, or barley, but only wild plants, with a significant presence of species (Rubiaceae) also employed for dyeing. The results of these analyses are preliminary and await further confirmation, but in any case, at this stage, a possible use of the area for textile activities is inferred.

\section{Area E: The Cemetery}

The Cemetery (Area E) extends along a series of 2 terraces sloping from the top mound to the southeast. The investigation within this area aimed at outlining the relationship with the sequence of phases evidenced on the top mound Workshop Complex and consequently clarifying the general chronology of the occupation of the site during the EC-LC I period (Bombardieri and Jasink 2010). Presently, the Area E consists of 7 rock-cut tombs (tombs 228-232, 240-241) excavated during the 2008-2010 field seasons. While tombs 228 and 230 were looted in antiquity, the other burials luckily were preserved. All the tombs show single, small, irregularly rounded chambers with a cave-like section. A short dromos (narrow entranceway) leads to the grave chamber of tombs 228-230 located 
on the upper terrace, where the stomion (a deep doorway) was roughly outlined by regularizing the terrace facade. On the other hand, tombs $231,232,240$, and 241 , located on a lower terrace, even though having the same basic plan, contain no dromos and suggest a wider dimensional variability.

The offering goods deposits display a wide repertoire of ceramics and small objects. The small finds and ceramic assemblages, based on their typology and decoration patterns, point to a standard South Coast production, mainly ranging from the EC III to MC III/LC I period, thus drawing a sequence of use contemporary with the stratigraphic deposits from the top mound Workshop Complex. In particular, it can be argued that tombs 231,232, 240 and 241, with offering deposits dating back to the EC III-MC I/II period, were contemporaneous with the earlier phase B, while the presence of later MC III/LC I materials from tombs 228,229 , and 230 correspond to later deposits dated to the more recent phase A (Bombardieri 2009).

Tombs 231 and 240 have the earliest assemblages, characterized by a repertoire typical of the EC to beginning of $\mathrm{MC}$ period. It is worth noting the discovery of a gourd juglet from Tomb 231, similar to those coming from EC III contexts at Marki-Alonia and Psamatismenos and assumed by Frankel and Webb (2006) to be imports from the North Coast. Indeed, comparable gourd juglets are commonly found in the North Coast region and have been similarly dated back to the EC IIIB-MC I period (Stewart 1962; Herscher 1991, 2003). More recent assemblages come from tombs 228 and 230, where the presence of Black Slip II and Red Polished Punctured ware, also known as Episkopi ware (Herscher 1991), points to a later date, the MC III-LC I period.

Concerning human remains, bones were only recovered from tombs 228 and 230. Poor preservation of bones is quite a common phenomenon in Cyprus; the low $\mathrm{pH}$ values of the soils, as those recorded in the Cemetery of Erimi-Laonin tou Porakou, could play a major role in bone diagenesis (see e.g. Nielsen-Marsh et al. 2007). In this case, the recovered bones also presented limestone incrustations on the whole surface, and it was almost impossible to perform a comprehensive anthropological study of the skeleton remains. Nevertheless, Tomb 228 contained a minimum of 5 individuals (4 adults and 1 subadult), suggesting a multiple burial. As for Tomb 230, the minimum number of individuals is 2 but, given the fact that the second individual is represented uniquely by 1 anatomic element, it is likely a reuse of the tomb rather than a multiple burial.

\section{MATERIALS AND METHODS}

During the 2010 field season, charcoal and bone samples were collected for ${ }^{14} \mathrm{C}$ dating. Three charcoal samples were taken from the storage area in the Workshop Complex: 1 sample (Ch_us394) came from the top soil, while the other 2 (Ch_us391 and Ch_us392) came from 2 stratigraphic units corresponding to fillings of a structure. Up to the present, no detailed paleobotanic analyses have been performed on the collected charcoals.

As for the Cemetery (Area E), a total of 9 samples were collected from the skeleton remains of tombs 228 and 230: 5 samples from the 5 individuals of Tomb 228 and 4 samples from the 2 individuals of Tomb 230. More specifically, for Tomb 228: samples T228_1, T228_2, T228_3, and T228_4 were taken from the femurs midshaft of the 4 adults and T228_sub from the humerus midshaft of the subadult. While for Tomb 230: T230_1_f, T230_1_o, and T230_1_t were obtained, respectively, from the femur, humerus, and tibia midshaft of the principal individual; T230_2 was taken from the humerus midshaft of the other individual. All collected samples were prepared and measured by accelerator mass spectrometry (AMS) at the LABEC (Laboratorio di Tecniche Nucleari per i Beni Culturali) Laboratory of INFN (Istituto Nazionale di Fisica Nucleare) in Florence. 
For the charcoal samples, after mechanical cleaning, chemical pretreatment was performed following the conventional ABA method (see e.g. Cartocci et al. 2007). The preservation state of the bone samples was quite bad as their surface was covered with calcareous incrustations. The samples were first crushed to small fragments in a mortar, then collagen was extracted using a modified Longin (1971) method. Taking their poor preservation state into account, a more diluted solution of $\mathrm{HCl}$ was used for the first step in demineralization of the samples. Chemical pretreatment was conducted according to the following steps:

- $0.5 \mathrm{M} \mathrm{HCl}$ at room temperature for half a day, then $\mathrm{HCl} 1 \mathrm{M}$ overnight to remove the inorganic fraction of bone;

- $0.1 \mathrm{M} \mathrm{NaOH}$ at room temperature for $1 \mathrm{hr}$, to purify the extracted collagen;

- $1 \mathrm{M} \mathrm{HCl}$ at room temperature for $2 \mathrm{hr}$, to remove any $\mathrm{CO}_{2}$ possibly absorbed from the atmosphere during the second step.

After each step, samples were rinsed with deionized water to neutral $\mathrm{pH}$. Finally, the solution of the organic residue was heated at $\mathrm{pH} \sim 3$ for $12 \mathrm{hr}$ at $80{ }^{\circ} \mathrm{C}$ to collect dissolved collagen as gelatin. In order to assess the quality of the extracted collagen, the $\mathrm{C} / \mathrm{N}$ atomic ratio of gelatin samples was measured with a CHN elemental analyzer (Thermo Finnigan Flash EA1112) - the same as used for sample combustion.

For all samples, the carbon dioxide originating from the combustion was reduced to graphite following our standard procedure (Fedi et al. 2007), by reaction with hydrogen at $\sim 600{ }^{\circ} \mathrm{C}$ and using iron as catalyst. ${ }^{14} \mathrm{C}$ concentrations of the unknown samples, expressed in pMC (percent of modern carbon), were calculated correcting the measured ${ }^{14} \mathrm{C} /{ }^{12} \mathrm{C}$ isotopic ratios for isotopic fractionation $\left({ }^{13} \mathrm{C} /\right.$ ${ }^{12} \mathrm{C}$ isotopic ratio is simultaneously measured in the AMS beam line during each run) and background, and then normalizing the corrected values to the isotopic ratio measured for a set of NIST oxalic acid II standards.

\section{RESULTS AND DISCUSSION}

The results of ${ }^{14} \mathrm{C}$ measurements for charcoal samples and bone samples are summarized in Tables 1 and 2, respectively. Measured ${ }^{14} \mathrm{C}$ ages were calibrated using the software OxCal v 4 (Bronk Ramsey 2009) and the internationally agreed calibration curve IntCal09 (Reimer et al. 2009).

Table 1 Conventional ${ }^{14} \mathrm{C}$ ages and calibrated ages of the charcoal samples.

\begin{tabular}{lll}
\hline Sample & $\begin{array}{l}\text { Conventional age } \\
\text { (yr BP) }\end{array}$ & $\begin{array}{l}\text { cal age } \\
\text { (95\% confidence level) }\end{array}$ \\
\hline Ch_us391 & $3750 \pm 30$ & $2280-2040 B C$ \\
Ch_us392 & $3795 \pm 35$ & $2400-2060 B C$ \\
Ch_us394 & $1000 \pm 35$ & $A D 975-1155$ \\
\hline
\end{tabular}

As seen in Table 1, samples Ch_us391 and Ch_us392 date back to the second half of the 3rd millennium $\mathrm{BC}$, corresponding to the Early Cypriote period. As stated above, the 2 samples came from contemporaneous contexts (US 391-392). The ${ }^{14} \mathrm{C}$ results are consistent with the period of occupation of the site and confirm the archaeological interpretation of the stratigraphic deposits in the Workshop Complex (Area A). The third sample (Ch_us394) was originally collected from the top filling soil; the date obtained by ${ }^{14} \mathrm{C}$ analysis covers the $10-11$ th centuries $\mathrm{AD}$, i.e. consistent with the Byzantine period. This date range seems plausible, but other data suggesting a stable Byzantine 
Table $2 \mathrm{C} / \mathrm{N}$ atomic ratios, average conventional ${ }^{14} \mathrm{C}$ ages, and calibrated ages of bone samples.

\begin{tabular}{|c|c|c|c|c|}
\hline Sample & $\mathrm{C} / \mathrm{N}$ & $\begin{array}{l}\text { Conventional age } \\
\text { (yr BP) }\end{array}$ & & $\begin{array}{l}\text { cal age }(\mathrm{BC}) \\
(95 \% \text { confidence level) }\end{array}$ \\
\hline T228_1 & 3.4 & $3145 \pm 30$ & & $1500-1380$ \\
\hline T228_sub & 5.7 & n.a. & & n.a. \\
\hline T228_3 & 4.0 & $2140 \pm 50$ & & $360-46$ \\
\hline T230_1_f & 3.4 & $3500 \pm 65$ & T230_1 & $1890-1690$ \\
\hline T230_1_o & 3.5 & $3450 \pm 55$ & (weighted average) & \\
\hline T230_2 & 3.4 & $3240 \pm 40$ & & $1610-1430$ \\
\hline
\end{tabular}

phase of occupation at Erimi-Laonin tou Porakou have not yet been found. Further investigations would be necessary to clarify this question.

Table 2 shows the results of the bone sample analyses; samples T228_2, T228_4, and T230_1_t are not included due to the insufficient yield of extracted collagen after pretreatment $(<<1 \%)$. As reported in De Niro (1985), a C/N atomic ratio in the range 2.9-3.6 is considered a good indicator of a well-preserved bone. Samples T228_1, T230_1_f, T230_1_o, and T230_2 gave average C/N atomic ratios of 3.4, indicating a very acceptable collagen quality. On the other hand, for samples T228_sub and T228_3, we measured $\mathrm{C} / \mathrm{N}$ atomic ratios of 5.7 and 4.0, respectively, which fall outside the recommended range. T228 sub did not produce enough carbon dioxide for the graphitization and could not be measured, while T228_3 has been dated to the second half of the 4th century to the first half of the 1st century BC, i.e. the Hellenistic Age. Since a $\mathrm{C} / \mathrm{N}$ atomic ratio greater than 3.6 indicates contamination of extraneous carbon, it can be argued that $\mathrm{T} 228$ _3, with its $\mathrm{C} / \mathrm{N}$ value of 4.0, was a contaminated sample. Samples T230_1_f and T230_1_o, on the other hand, proved to be consistent; therefore, as the anthropological analyses determined they belonged to the same individual, the best ${ }^{14} \mathrm{C}$ age estimate was calculated as their weighted average.

All the results for the Cemetery, Area E, can be summarized as follows (see Table 2): 1 individual from Tomb 230 has been dated to the 18th-19th centuries BC (generally corresponding to Middle Cypriote) while the other 2 individuals, one from Tomb 228 and the other from Tomb 230, date to the 15-16th centuries BC (broadly corresponding to Late Cypriote I). The analyses of the material assemblages from the offering-goods deposits of tombs 228 and 230 determined that the 2 burials were contemporaneous to phase A, i.e. ranging from MC III to LC I.

In conclusion, the samples measured by ${ }^{14} \mathrm{C}$ AMS provide absolute dates consistent with the analyses of the material assemblages, thus confirming the chronological sequence suggested by the archaeological evidence. As documented by the stratigraphic deposit of the Workshop Complex (Area A) and the chronological range of the funerary goods from the Cemetery (Area E), the chronological sequence at Erimi-Laonin tou Porakou contains 2 main phases (phase A and phase B) consistent with Bronze Age occupation of the site (see Table 3). The earlier phase B, ranging from EC III to MC I/II, corresponds to the beginning and progressively increasing workshop activity, which led to the first installation of an organized complex. After a (sudden) destruction episode, the storage area was rebuilt on a slightly different plan, probably maintaining the same function. This phase corresponds to the more recent phase $\mathrm{A}$, ranging from MC III to LC I, and is marked by the organization of a new workshop activity during which some of the former installations were reused while others were built as new. Phase A is then followed by a collapse and finally by a phase of definitive abandonment of the site. 
Table 3 Chronological sequence at Erimi-Laonin tou Porakou. References to contexts (US) and ceramic vessels follow Bombardieri (forthcoming).

\begin{tabular}{|c|c|c|c|}
\hline \multicolumn{3}{|c|}{ Workshop Complex (Area A) } & Cemetery (Area E) \\
\hline Abandon & nent & Top filling humus (US 342) & \multirow{3}{*}{$\begin{array}{l}\text { Tomb } 228 \\
\text { Bone sample T228_1 } \\
\text { Tomb 230 } \\
\text { Bone samples T230_2 } \\
\text { T230_1_f, T230_1_0 } \\
\text { Tomb229 }\end{array}$} \\
\hline \multirow{2}{*}{$\begin{array}{l}\text { Phase A } \\
\text { MCIII- } \\
\text { LCI }\end{array}$} & Collapse & Mudbricks/stone debris (US 354+351) & \\
\hline & $\begin{array}{l}\text { Storage } \\
\text { activity }\end{array}$ & $\begin{array}{l}\text { Installation, devices (Bench US 357); in- } \\
\text { side wall (US 355); ceramic vessels (SAI:1- } \\
6,8,9,19)\end{array}$ & \\
\hline \multirow{2}{*}{$\begin{array}{l}\text { Phase B } \\
\text { ECIII - } \\
\text { MCI/II }\end{array}$} & Destruction & Ashes/mudbrick debris (US 362) & \multirow{2}{*}{$\begin{array}{l}\text { Tombs } 231,232,240 \text {, } \\
241\end{array}$} \\
\hline & $\begin{array}{l}\text { Workshop } \\
\text { activity }\end{array}$ & $\begin{array}{l}\text { Installation, devices (Bench US 357, basin } \\
\text { US 373); ceramic vessels (SAI:7, 10-18) } \\
\text { Charcoal samples Ch_us391, Ch_us392 }\end{array}$ & \\
\hline
\end{tabular}

In light of these recent results, the evidence discovered at Erimi-Laonin tou Porakou adds to the knowledge of the Early to Late Cypriote period in the Kourion area. Of course, some questions are still unanswered: the use and function of the Workshop Complex is still uncertain as well as many aspects related to the burial customs that need to be cleared. Luckily, unresolved questions can prompt different methods of investigation: in this case, future paleobotanical analyses and stable isotope analyses for paleodiet could be combined with ${ }^{14} \mathrm{C}$ results and archaeological evidence in order to find possible solutions.

\section{ACKNOWLEDGMENTS}

The archaeological research project of the University of Florence at Erimi-Laonin tou Porakou is carried out thanks to scientific collaboration of the Department of Antiquities of Cyprus. We express our gratitude to the Director of the Department of Antiquities, Dr M Hadjikosti, for granting the permission to develop the research project at Erimi, to Mr Y Violaris, for his support and suggestions, and to the kind cooperation of the staff of the District Archaeological Museum of Limassol. Thanks are due to the following team members and specialists: M L Amadio, M Faggi, F Chelazzi, M Marino, F Dolcetti, E Stephani, G Dionisio, A Criscione, E Bertazzoli, M Carra, and E Albertini. Finally, we thank Prof A M Jasink of the University of Florence and the staff of the Italian Embassy in Nicosia for their support, particularly Ambassador A Bastianelli and M Carnelos, Deputy Head of Mission. The project is grateful to the Institute of Aegean Prehistory of Philadelphia (INSTAP), the Italian Ministry of Foreign Affairs, the University of Florence - Facoltà di Lettere e Filosofia, the Mediterranean Archaeological Trust, and the Ente CRF for funding and support of the 2008-2010 field seasons. Financial support from Regione Toscana (in the framework of the TEMART project POR CReO/FESR 2007-2013) is gratefully acknowledged for M E Fedi's position within INFN.

\section{REFERENCES}

Belgiorno MR. 2005. Short report of the first survey made at Erimi-Kafkalla (October 2004). Report of the Department of Antiquities, Cyprus 2004. p 225-30.

Bombardieri L. 2009. The MBA-LBA I period in the Kourion region: new evidences from Erimi-Laonin tou Porakou (Lemesos, Cyprus). Antiguo Oriente 7: 281-300.
Bombardieri L. 2010. Surveying the Kourion land: field survey of the Kouris Valley and preliminary excavations at Erimi-Laonin tou Porakou (2007-2008 seasons). In: Jasink AM, Bombardieri L, editors. Researches of Cypriote History and Archaeology. Florence, 29-30 April 2009. Florence: Firenze University Press. p 33-52. 
Bombardieri L. Forthcoming. Excavation at Erimi-Laonin tou Porakou: 2009 Preliminary Report, Report of the Department of Antiquities, Cyprus 2010.

Bombardieri L, Chelazzi F. Forthcoming. Land use and settlement patterns in the Kourion region: a crossanalysis of the MC-LC topography and pottery evidence. In: Jacobs A, Nys K, editors. Cypriot Material Culture Studies: From Picrolite Carving to Proskynetaria. Proceedings of the 8th Annual Postgraduate Cypriot Archaeology Conference Held in Memory of Paul Åström, Vrije Universiteit Brussel, 27-29 November 2008. Brussels: Paul Aströms Förlag.

Bombardieri L, Jasink AM. 2010. The Kouris Valley Project 2007-2009: an overview. Res Antiquae 7:26370.

Bombardieri L, Menozzi O, Fossalaro D, Jasink AM. 2009. Preliminary excavations at Erimi-Laonin tou Porakou (Lemesos, Cyprus). Report of the Department of Antiquities, Cyprus 2009. p 131-62.

Bronk Ramsey C. 2009. Bayesian analysis of radiocarbon dates. Radiocarbon 51(1):337-60.

Cartocci A, Fedi ME, Taccetti F, Benvenuti M, Chiarantini L, Guideri S. 2007. Study of a metallurgical site in Tuscany (Italy) by radiocarbon dating. Nuclear Instruments and Methods in Physics Research B 259(1): 384-7.

De Niro MJ. 1985. Postmortem preservation and alteration of in vivo bone collagen isotope ratios in relation to palaeodietary reconstruction. Nature $317(6040)$ : 806-9.

Fedi ME, Cartocci A, Manetti M, Taccetti F, Mandò PA. 2007. The ${ }^{14} \mathrm{C}$ AMS facility at LABEC, Florence. $\mathrm{Nu}$ clear Instruments and Methods in Physics Research B 259(1):18-22.

Frankel D, Webb JM. 2006. Marki Alonia. An Early and Middle Bronze Age settlement in Cyprus. Excavations 1995-2000. Studies in Mediterranean Archaeology $123, \mathrm{nr} 2$.
Herscher E. 1991. Beyond regionalism: toward an island wide Middle Cypriote sequence. In: Barlow JA, Barlow DL, Kling B, editors. Cypriot Ceramics: Reading the Prehistoric Record. Philadelphia: University of Pennsylvania Museum of Archaeology and Anthropology. p 45-50.

Herscher E. 2003. The ceramics. In: Swiny S, Rapp G, Herscher E, editors. Sotira-Kaminoudhia. An Early Bronze Age Site in Cyprus. Boston: American Schools of Oriental Research. p 145-210.

Longin R. 1971. New method of collagen extraction for radiocarbon dating. Nature 230(5291):241-2.

Manning SW, Swiny S. 1994. Sotira Kaminoudhia and the chronology of the Early Bronze Age in Cyprus. Oxford Journal of Archaeology 13:149-72.

Manning SW, Weninger B, South AK, Kling B, Kuniholm PI, Muhly JD, Hadjisavvas S, Sewell DA, Cadogan G. 2001. Absolute age range of the Late Cypriot IIC Period on Cyprus. Antiquity 75(288):328-40.

Nielsen-Marsh CM, Smith CI, Jans MME, Nord A, Kars H, Collins MJ. 2007. Bone diagenesis in the European Holocene II: taphonomic and environmental considerations. Journal of Archaeological Science 34(9): 1523-31.

Reimer PJ, Baillie MGL, Bard E, Bayliss A, Beck JW, Blackwell PG, Bronk Ramsey C, Buck CE, Burr GS, Edwards RL, Friedrich M, Grootes PM, Guilderson TP, Hajdas I, Heaton TJ, Hogg AG, Hughen KA, Kaiser KF, Kromer B, McCormac FG, Manning SW, Reimer RW, Richards DA, Southon JR, Talamo S, Turney CSM, van der Plicht J, Weyhenmeyer CE. 2009. IntCal09 and Marine09 radiocarbon age calibration curves, 0-50,000 years cal BP. Radiocarbon 51(4): $1111-50$.

Stewart JR. 1962. The Early Cypriote Bronze Age. In: Dikaios P, Stewart JR, editors. The Stone Age and the Early Bronze. The Swedish Cyprus Expedition. Volume IV, part IA. Lund. p 205-401. 